\title{
MASA DEPAN PENGEMBANGAN USAHA KECIL DAN MENENGAH (UKM): PERSPEKTIF JARINGAN PERUSAHAAN DAN KEBIJAKAN
}

\author{
Mumuh Muksin \\ UIN Sunan Gunung Djati Bandung \\ Email: mumuhmuksin@yahoo.co.id
}

\begin{abstract}
Abstrak
Kami meninjau kebijakan yang mendukung UKM dalam berbagai bidang. Tinjauan kami menunjukkan bahwa pendapat-pendapat yang mengemukakan bahwa mensubsidi kegiatan UKM (berbeda dari beberapa kegiatan perusahaan terlepas dari ukurannya) tidak dibenarkan secara ekonomi. Meskipun demikian, secara luas diakui bahwa UKM menderita relatif kerugian terhadap perusahaan besar, terutama di bidang akses ke informasi dan teknologi. Kami kemudian mempelajari kemungkinan yang ditawarkan oleh jaringan dalam membantu UKM menangani kerugian yang mereka alami. Penelitian kami menunjukkan bahwa ada manfaat yang diperoleh perusahaan dari berpartisipasi dalam jaringan. Lebih lanjut, karena jaringan dapat membantu perusahaan mengatasi beberapa kerugian bawaan mereka, mereka dapat menjadi tidak bergantung pada bantuan publik dan lebih mampu bersaing dengan perusahaan yang lebih besar begitu dorongan awal diberikan untuk pembentukan jaringan kerja sama yang dapat memungkinkan perusahaan untuk bersaing lebih efektif.
\end{abstract}

Kata Kunci: Kebijakan, Pemerintah, Usaha Kecil dan Menengah, Jaringan.

\begin{abstract}
We review policies that support SMEs in various fields. Our review shows that opinions suggesting that subsidizing SME activities (different from some company activities regardless of size) is not economically justified. Nonetheless, it is widely recognized that SMEs suffer relative losses to large companies, especially in the area of access to information and technology. We then study the possibilities offered by the network in helping SMEs deal with the losses they experience. Our research shows that there are benefits to companies from participating in networks. Furthermore, because networks can help companies overcome some of their innate losses, they can become independent of public assistance and be better able to compete with larger companies once initial impetus is given for the establishment of cooperative networks that can enable companies to compete more effectively.
\end{abstract}

Keywords: Policy, Government, Small and Medium Enterprises, Networks.

\section{A. PENDAHULUAN}

Kebijakan untuk mempromosikan pengembangan UKM merupakan hal yang umum di negara maju dan berkembang (Storey, 1994; Levitsky, 1996; Hallberg, 2000). Dalam kasus negara maju, sudah menjadi hal biasa bagi pemerintah selama dua atau tiga dekade terakhir 
untuk mengimplementasikan kebijakan atau program yang dirancang untuk mempromosikan aspek usaha kecil dan menengah (UKM). Ini bertepatan dengan peningkatan pentingnya, dalam hal kontribusi terhadap lapangan kerja dan pertumbuhan PDB, dari UKM di sebagian besar negara maju (Storey, 1994).

Di negara-negara OECD, UKM saat ini menyumbang lebih dari 95 persen perusahaan dan 60-70 persen lapangan kerja (OECD, 2000). Ini sebagian merupakan hasil dari proses restrukturisasi industri yang dimulai pada akhir 1970-an yang melihat perusahaan besar secara substansial mengurangi output dan tenaga kerja mereka, menciptakan kumpulan besar pekerja yang menganggur, sebagian dari mereka termotivasi untuk memulai bisnis mereka sendiri (Storey, 1982). Proses itu diberi dorongan tambahan dengan langkah menuju privatisasi dan deregulasi pasar pada akhir 1980-an dan 1990-an, menghasilkan tren organisasi yang luas yang mencakup outsourcing dan perampingan (Parker, 2000). Perkembangan dalam teknologi informasi dan komunikasi, meningkatnya kemakmuran dan pengembangan ceruk pasar, serta semakin pentingnya skala ekonomi sebagai sumber utama daya saing, juga berkontribusi pada pertumbuhan sektor UKM di negara maju.

Dalam kasus ekonomi berkembang, kebijakan yang dirancang untuk membantu UKM telah menjadi aspek penting dari kebijakan industri dan program bantuan multilateral seperti yang dilakukan PBB sejak 1950-an (Levitsky, 1996). Usaha mikro dan kecil memainkan peran penting dalam pengentasan kemiskinan dan memberdayakan kelompok-kelompok tertentu termasuk perempuan. Selain itu, pergerakan oleh beberapa ekonomi berkembang yang sebelumnya direncanakan secara terpusat (seperti Vietnam dan Cina) dan ekonomi yang sangat diatur seperti India menuju deregulasi dan ekonomi berorientasi pasar, dengan penekanan pada pengembangan ekonomi berorientasi sektor swasta yang dinamis, telah memberikan dorongan lebih lanjut kepada pengembangan usaha kecil di banyak negara berkembang. Namun, meskipun ada variasi yang luas di berbagai negara, gambaran tradisionalnya adalah di mana kepentingan relatif UKM cenderung menurun ketika suatu negara naik tangga pembangunan (lihat misalnya Hallberg, 2000; Liedholm \& Meade, 1999). Proses globalisasi, ditandai dengan meningkatnya arus perdagangan dan modal, pembukaan pasar dan liberalisasi dan arus pengetahuan, telah menghasilkan sumber dan pemasaran global untuk perusahaan besar. Outsourcing dan meningkatnya keterlibatan bisnis kecil dalam rantai pasokan korporasi transnasional besar telah memberi mereka banyak 
peluang bisnis. Karenanya penurunan tradisional dalam peran dan pentingnya UKM di negara-negara berkembang kemungkinan akan berubah di masa depan.

Seperti yang ditunjukkan oleh data yang tersedia negara-negara anggota APEC, UKM menyumbang proporsi signifikan dari tenaga kerja di negara maju dan berkembang (lihat Tabel 1). Selain itu, mereka juga terdiri dari proporsi yang signifikan dari perusahaan bisnis (lihat Tabel 2). Karena itu dapat dikatakan bahwa, murni dari sudut pandang signifikansi mereka dalam ekonomi mereka, UKM memerlukan perhatian dari pemerintah. Storey (1994) berpendapat, dalam konteks Inggris, bahwa peningkatan kepentingan dari UKM berarti bahwa kebijakan publik terhadapnya tidak dapat terpisah dari pengaruh lain dalam ekonomi dan tidak dapat diserahkan kepada mereka yang memiliki minat khusus pada UKM.

Pentingnya UKM dalam ekonomi mereka membuatnya penting bagi pembuat kebijakan untuk memastikan bahwa perusahaan-perusahaan ini tidak menghadapi hambatan yang menghambat kemampuan mereka untuk beroperasi secara efisien dan tidak menghadapi biaya kepatuhan administrasi yang berat. Namun, kita harus berhati-hati, jangan sampai menyimpulkan bahwa ini harus mengikuti kebijakan yang secara khusus mendukung UKM dari pada perusahaan besar harus dilaksanakan. Seperti Lattimore et al. (1998) mencatat, "sementara kepentingan ekonomi memberikan dasar yang kuat untuk konsultasi kebijakan publik dengan bisnis kecil, dalam dirinya sendiri ia memberikan sedikit pembenaran untuk intervensi spesifik".

Tabel 1 Kontribusi Usaha Mikro, Kecil dan Menengah untuk Pekerjaan Swasta Bukan Pertanian, Negara-Negara APEC Pilihan (\%)

\begin{tabular}{|l|c|c|c|c|}
\hline \multicolumn{1}{|c|}{ Negara } & $\begin{array}{c}\text { Mikro } \\
\text { (<5karyawan) }\end{array}$ & $\begin{array}{c}\text { Kecil } \\
(5-19 \\
\text { karyawan })\end{array}$ & $\begin{array}{c}\text { Medium } \\
(20-99 \\
\text { karyawan })\end{array}$ & $\begin{array}{c}\text { Semua } \\
\text { UKM }\end{array}$ \\
\hline Australia & 25.9 & 20.9 & 19.2 & 66.0 \\
\hline Hong Kong, Cina & 31.1 & 13.0 & 24.8 & 59.4 \\
\hline Jepang & 13.1 & 29.9 & 26.9 & 69.9 \\
\hline Korea & 31.2 & 11.3 & 36.2 & 78.7 \\
\hline Meksiko & 36.2 & 13.9 & 15.2 & 65.2 \\
\hline Selandia Baru & 23.0 & 18.0 & 19.0 & 60.0 \\
\hline Peru & 62.5 & 16.6 & 8.8 & 87.9 \\
\hline Filipina & 36.7 & 25.8 & 7.1 & 69.5 \\
\hline Singapura & 7.1 & 16.8 & 19.2 & 43.1 \\
\hline Amerika Serikat & 5.2 & 13.6 & 17.9 & 36.7 \\
\hline
\end{tabular}

Sumber: Hall (2002) 
Tabel 2

Jumlah UKM Non-Pertanian Swasta sebagai Persentase Perusahaan, Negara-Negara APEC Terpilih (\%)

\begin{tabular}{|l|c|c|c|c|}
\hline \multicolumn{1}{|c|}{ Negara } & $\begin{array}{c}\text { Mikro } \\
\text { (<5karyawan) }\end{array}$ & $\begin{array}{c}\text { Kecil } \\
(5-19 \\
\text { karyawan })\end{array}$ & $\begin{array}{c}\text { Medium } \\
(20-99 \\
\text { karyawan })\end{array}$ & $\begin{array}{c}\text { Semua } \\
\text { UKM }\end{array}$ \\
\hline Australia & 69.9 & 24.3 & 4.9 & 99.0 \\
\hline Chili & 82.1 & 15.0 & 2.1 & 99.1 \\
\hline Hong Kong, Cina & 86.8 & 7.6 & 4.9 & 99.3 \\
\hline Jepang & 56.5 & 34.7 & 7.4 & 98.7 \\
\hline Korea & 72.7 & 17.8 & 8.6 & 99.1 \\
\hline Meksiko & 91.7 & 6.3 & 1.6 & 99.6 \\
\hline Selandia Baru & 84.2 & 7.1 & 8.0 & 99,4 \\
\hline Peru & 96.5 & 3.1 & 0,3 & 99.9 \\
\hline Filipina & 91.1 & 8.2 & 0,4 & 99.6 \\
\hline Singapura & 67.4 & 24.3 & 6.1 & 97.8 \\
\hline Thailand & 79.0 & 18.4 & 2.0 & 99,4 \\
\hline Amerika Serikat & 60.5 & 28.9 & 8.9 & 98.3 \\
\hline
\end{tabular}

Sumber: Hall (2002)

Banyak kebijakan yang berkaitan dengan UKM didasarkan pada kelemahan atau kekurangan yang dirasakan yang mereka derita terhadap perusahaan besar. Studi masalah yang dihadapi oleh UKM telah menyimpulkan bahwa mereka menderita kelemahan yang sama di negara-negara berkembang seperti yang mereka lakukan di negara-negara maju (Levitsky, 1996). Namun, masalah dengan kebijakan pemerintah sehubungan dengan UKM adalah bahwa mereka cenderung dicirikan oleh kurangnya koherensi, seperti yang diamati oleh Storey (1994) dalam konteks negara-negara Eropa, di mana "kebijakan publik telah dikembangkan, disingkirkan, dan seringkali diperkenalkan kembali secara sedikit demi sedikit.

Pengamatan ini sebagian besar berkaitan juga dengan UKM di negara-negara maju dan menunjukkan kesulitan utama dalam kebijakan yang dirancang untuk memenuhi pengelompokan perusahaan yang beragam. Namun, tren saat ini, di negara-negara maju dan berkembang, menunjukkan bahwa kebijakan publik semakin difokuskan pada strategi yang berorientasi pasar dan pembentukan lapangan permainan yang setara untuk semua perusahaan, daripada, seperti di masa lalu, langkah-langkah langsung ditujukan pada, misalnya, mengurangi biaya kredit. Literatur usaha mikro sangat relevan dalam menjelaskan perubahan penekanan ini.

Kami menawarkan kategorisasi dan penilaian kritis dari berbagai kebijakan. Seperti yang dikatakan oleh Storey (1994), “Tujuan utama dari kebijakan ekonomi makro tidak 
semata-mata untuk membantu perusahaan yang lebih kecil, tetapi untuk menyediakan kerangka kerja untuk semua ukuran perusahaan dalam perekonomian untuk berkembang. Dengan demikian, tes yang harus dilewati oleh kebijakan atau program yang mendukung UKM adalah bahwa ia tidak hanya harus memiliki alasan ekonomi yang sehat tetapi juga, mengingat biaya desain dan implementasi program-program tersebut dan kemungkinan distorsi terhadap insentif bisnis, menunjukkan bahwa mampu memberikan manfaat kesejahteraan bersih bagi masyarakat secara keseluruhan. Kami memeriksa setiap argumen kebijakan dari sudut pandang ini.

\section{B. TINJAUAN PUSTAKA}

Tujuan terluas dari kebijakan UKM adalah ekonomi makro. Ini termasuk penciptaan lapangan kerja. Seperti yang dicatat oleh Levitsky (1996) dalam kasus program bantuan donor yang menargetkan UKM di negara-negara berkembang, "semua program dibenarkan dengan berargumen bahwa perusahaan kecil menghasilkan lebih banyak pekerjaan untuk investasi modal langka yang diberikan. Para donor juga memandang usaha kecil sebagai cara menyebar pembangunan ekonomi dan meningkatkan standar hidup penduduk di pedesaan. Penciptaan lapangan kerja juga merupakan tujuan utama dari banyak kebijakan UKM di negara-negara maju (de Koning et al., 1992; Revesz \& Lattimore, 1997).

Karena UKM menyumbang proporsi signifikan pada penciptaan lapangan kerja, maka kebijakan selektif yang bertujuan menciptakan lapangan kerja dalam usaha kecil harus dikejar. Analisis yang lebih baru menunjukkan kelemahan dalam alasan untuk tujuan seperti itu. Revesz dan Lattimore (1997), misalnya, berdebat menentang mengadopsi pendekatan semacam itu atas beberapa alasan. Meskipun argumen mereka terkait dengan kasus Australia, mereka sebagian besar berlaku untuk negara lain juga.

Revesz dan Lattimore (1997) mencatat pernyataan bahwa perusahaan kecil adalah sumber utama pekerjaan baru didasarkan pada data cross-sectional yang tidak meyakinkan, menunjukkan bahwa belum ada studi longitudinal jangka panjang tentang penciptaan lapangan kerja yang telah dilakukan. Lebih jauh, bahkan jika memang benar bahwa usaha kecil telah menciptakan banyak lapangan kerja baru, tidak berarti bahwa kebijakan untuk mempromosikan sektor UKM dibenarkan. Pertama, mereka mencatat bahwa meskipun sektor UKM mungkin merupakan tempat di mana banyak pekerjaan baru telah dibuat, ini tidak berarti bahwa mereka bertanggung jawab atas hal tersebut dan, memang, mereka berpendapat bahwa banyak pekerjaan baru diciptakan di sektor ini bukan karena UKM lebih mampu 
menghasilkan pekerjaan baru tetapi karena produk yang permintaannya meningkat sebagian besar dipasok oleh UKM. Yaitu, tren terkini dalam pangsa pekerjaan mencerminkan perubahan dalam pola permintaan dalam perekonomian (Lattimore et al., 1998) dan ada apa yang Revesz dan Lattimore (1997) sebut sebagai "kebingungan medium dan penyebab". Implikasinya, kebijakan yang mempromosikan UKM akan disalahpahami jika pola permintaan bergeser di masa depan.

Kedua, Revesz dan Lattimore (1997) berpendapat bahwa, mengingat bahwa ukuran optimal dari unit bisnis ditentukan oleh teknologi dan biaya transaksi, intervensi pemerintah dapat berfungsi untuk mendistorsi distribusi optimal ukuran perusahaan. Ketiga, mereka berpendapat bahwa tingkat kelangsungan hidup perusahaan kecil jauh lebih rendah daripada perusahaan besar, sehingga kebijakan selektif yang mendukung perusahaan kecil dapat meningkatkan turbulensi, dengan biaya sosial dan ekonomi yang menyertainya. Keempat, subsidi menyiratkan pajak yang lebih tinggi, yang dapat mengurangi insentif untuk bekerja di samping menciptakan distorsi di sektor-sektor ekonomi lainnya. Selanjutnya, setiap subsidi ke satu sektor ekonomi dengan mengorbankan sektor-sektor lain, atau dibiayai oleh pajak tambahan, harus dibenarkan atas dasar bahwa manfaat kesejahteraan untuk masyarakat dari subsidi tersebut adalah positif (Storey, 1994; Belli, 1997).

Akhirnya, Revesz dan Lattimore (1997) berpendapat bahwa program bantuan pemerintah untuk perusahaan "kecil" dapat menjadi kontraproduktif jika mereka mengurangi insentif untuk pertumbuhan bisnis yang akan melebihi ambang batas definisi perusahaan kecil. Levitsky (1996) melaporkan bukti dari India pada 1980-an yang menunjukkan bahwa kebijakan pemerintah tentang bantuan konsesi kepada UKM adalah "menghambat pertumbuhan banyak perusahaan yang memilih untuk tetap kecil daripada kehilangan status istimewa " dan memang mungkin telah mengurangi daya saing industri secara keseluruhan.

Bantuan untuk UKM kadang-kadang dibenarkan oleh pemerintah dengan dasar bahwa distribusi pendapatan yang ada kurang adil secara sosial. Badan-badan bantuan yang beroperasi di negara-negara berkembang telah ditarik untuk memberikan bantuan kepada usaha kecil sebagai cara pengentasan kemiskinan dan meningkatkan distribusi pendapatan (Levitsky, 1996). Hal ini sering dikaitkan dengan tujuan lain seperti menciptakan lapangan kerja, pelatihan, menyebar manfaat pembangunan ke daerah pedesaan dan melayani pasar pedesaan melalui program usaha kecil pedesaan, dan mempromosikan kewirausahaan masyarakat adat. Namun, seperti yang ditunjukkan Hallberg (2000), "Pemilik dan pekerja 
UKM tidak mungkin menjadi yang termiskin dari yang miskin, sehingga promosi UKM mungkin bukan instrumen pengentasan kemiskinan yang paling efektif. "

Untuk negara-negara maju, justifikasi redistribusi pendapatan mungkin bahkan lebih menarik. Storey (1982), berpendapat, dalam konteks Inggris, bahwa bantuan keuangan untuk perusahaan kecil akan paling bermanfaat bagi orang yang relatif kaya yang lebih mampu memulai bisnis baru mengutip bukti bahwa meskipun ada lebih banyak pengusaha" kelas pekerja" dari pada "kelas menengah", perusahaan kecil lebih mungkin dimulai oleh orangorang dari latar belakang kelas menengah daripada mereka yang memiliki latar belakang kelas pekerja. Selain itu, ada metode yang lebih langsung seperti transfer pendapatan untuk mencapai tujuan redistribusi pendapatan yang cenderung lebih efektif daripada kebijakan dukungan UKM (Hallberg, 2000).

\section{HASIL DAN PEMBAHASAN}

Ada peningkatan pengakuan bahwa kolaboratif dan jenis lain dari jaringan perusahaan menawarkan cara di mana perusahaan kecil dapat menghindari beberapa kelemahan yang terkait dengan kurangnya ukuran mereka. Selain itu, jaringan tersebut dapat mempromosikan berbagi pengetahuan, spesialisasi dan mengeksploitasi ekonomi produksi bersama (Lattimore et al., 1998). Humphrey \& Schmitz (1996) mengutip semakin banyak bukti di negara maju dan berkembang bahwa jejaring membantu UKM menjadi lebih kompetitif. Akibatnya, pemerintah semakin mempromosikan jaringan perusahaan, khususnya di antara perusahaan kecil. Intervensi pemerintah untuk mempromosikan jaringan kerja sama seperti itu akan tampak dibenarkan secara ekonomi karena (1) manfaat, dalam hal efisiensi statis dan dinamis dan peningkatan daya saing, yang berasal dari kerja sama tersebut; dan (2) kesulitan nyata dalam koordinasi yang dialami oleh perusahaan dalam memprakarsai pembentukan jaringan. Pada bagian ini, kami meninjau beberapa literatur terbaru tentang jaringan perusahaan dan mengeksplorasi implikasi untuk kebijakan.

\section{Jenis Jaringan}

Sejumlah taksonomi jaringan perusahaan telah diidentifikasi dalam literatur. Contohcontoh tipikal berdasarkan geografis, tetapi ini bukan satu-satunya bentuk jaringan yang mungkin. Humphrey \& Schmitz (1995:8-9), mengidentifikasi 3 jenis jaringan perusahaan. Sebuah klaster adalah konsentrasi sektoral dan geografis perusahaan. Beberapa manfaat yang timbul dari konsentrasi seperti itu, yang dikenal sebagai "ekonomi eksternal " 
termasuk munculnya pemasok yang melayani perusahaan-perusahaan di kluster, munculnya kumpulan pekerja dengan keterampilan yang dibutuhkan oleh sektor, dan kemungkinan munculnya agen pemasaran atau distribusi yang menyediakan tautan layanan ke pasar yang lebih jauh.

Jenis kedua dari jaringan perusahaan yang diidentifikasi oleh Humphrey dan Schmitz (1995) adalah kawasan industri. Menurut Rabellotti (1995), sebuah distrik industri muncul ketika sebuah klaster berkembang di luar spesialisasi dan pembagian kerja antar perusahaan, dan mengembangkan "bentuk kolaborasi implisit dan eksplisit antara agen ekonomi lokal di dalam distrik, meningkatkan produksi lokal dan kadang-kadang kemampuan inovasi" (Rabellotti, 1995). Rabellotti mendefinisikan kawasan industri dalam hal empat faktor utama: Sekelompok perusahaan yang secara geografis proksi dan khusus secara sektoral (terutama UKM); Baik keterkaitan ke depan dan ke belakang di antara perusahaan, berdasarkan pertukaran barang dan informasi pasar dan non-pasar; Latar belakang budaya dan sosial yang umum yang menghubungkan perusahaan dan menciptakan kode perilaku, terkadang eksplisit tetapi seringkali implisit; dan Pemerintah daerah dan kota yang mendukung.

Akhirnya, Humphrey dan Schmitz (1995) menggunakan istilah jaringan untuk merujuk pada kerjasama perusahaan dari perusahaan yang menunjukkan efisiensi kolektif, yang tidak selalu terkait dengan berada di lokasi yang sama, meskipun sebagian besar jaringan yang telah dipelajari terkonsentrasi secara geografis. Sementara ekonomi eksternal jaringan yang tidak terkonsentrasi secara geografis cenderung kecil, keuntungan dari aksi bersama bisa sangat besar (Humphrey \& Schmitz, 1995) dan mungkin memberikan motivasi untuk jaringan. Kami menggunakan jaringan istilah umum untuk merujuk ke ketiganya.

Taksonomi lain, yang lebih umum digunakan, mengambil perspektif rantai pasokan dalam membedakan antara jaringan horisontal (atau lateral) dan vertikal (misalnya, Berry, 1997; Nooteboom, 1999; Fritsch, 2001). Memang, Berry (1997), berpendapat bahwa perbedaan antara kerjasama perusahaan kecil-besar (terdiri terutama hubungan subkontrak vertikal) dan kerjasama perusahaan kecil-kecil adalah yang analitis dasar. Hubungan jaringan horizontal adalah hubungan antara perusahaan pada tingkat yang sama dalam rantai pasokan, sedangkan hubungan vertikal adalah antara perusahaan di berbagai tingkat rantai pasokan, biasanya dengan pemasok atau pelanggan. Bentuk persis yang dimanifestasikan dalam praktik bervariasi menurut industri dan ditentukan oleh, antara lain, perbedaan dalam teknologi dan struktur pasar (Berry, 1997). Namun, sementara perbedaan berfungsi sebagai 
titik awal yang mudah untuk analisis, Berry (1997) berpendapat bahwa kunci untuk memahami jaringan bukanlah banyak perbedaan struktural statis tetapi "untuk memahami proses dinamis dimana perusahaan dan sektor ditransformasikan untuk menciptakan sistem yang akhirnya muncul. "Ini menggemakan tema yang terdengar sebelumnya dalam Humphrey (1995) yang menekankan perlunya studi lebih lanjut tentang proses perubahan yang menghasilkan kegagalan atau keberhasilan jaringan.

\section{Konsep Jaringan}

Jaringan oleh perusahaan kecil memungkinkan mereka untuk memperoleh keuntungan efisiensi. Inti dari memahami bagaimana ini terjadi adalah konsep ekonomi eksternal, yang dapat ditelusuri untuk analisis Alfred Marshall tentang distrik industri abad ke-19 di Inggris (Humphrey dan Schmitz, 1995, 1996). Marshall mencatat ekonomi yang "sering dapat diamankan dengan konsentrasi banyak usaha kecil dengan karakter yang sama di wilayah tertentu". Contoh ekonomi eksternal tersebut termasuk akumulasi kumpulan pekerja khusus, akses mudah ke pemasok input dan layanan khusus, dan penyebaran pengetahuan yang siap di antara perusahaan-perusahaan di cluster (Schmitz dan Nadvi, 1999). Ekonomi eksternal adalah efek insidental yang dihasilkan sebagai konsekuensi yang tidak diinginkan dari kegiatan lain yang secara sadar (atau sengaja) dilakukan sebagai tindakan bersama. Ada dua jenis tindakan bersama: masing-masing perusahaan bekerja sama, misalnya, dalam berbagi peralatan atau dalam pengembangan produk; dan kelompok perusahaan yang bekerja sama dalam asosiasi bisnis, konsorsium, dan lain-lain. (Humphrey dan Schmitz, 1995, 1996).

Efek insidental dan disengaja digabungkan ke dalam konsep efisiensi kolektif, yang dapat didefinisikan sebagai "keunggulan kompetitif yang berasal dari ekonomi eksternal dan aksi bersama" (Schmitz \& Nadvi, 1999). Definisi ini menekankan gagasan bahwa daya saing dalam konteks ini tidak dapat dipahami dengan berfokus pada masing-masing perusahaan. Contoh keuntungan efisiensi kolektif yang timbul dari sekelompok produsen produk serupa termasuk keuntungan dari spesialisasi, daya tarik oleh kelompok pemasok dan pembeli, penciptaan kumpulan pekerja khusus, dan difusi pengetahuan siap pakai antar perusahaan dalam kelompok. Keuntungan efisiensi bisa statis, seperti ketersediaan input yang mudah, atau dinamis, seperti penyebaran ide-ide baru yang lebih cepat (Humphrey \& Schmitz, 1995). 
Namun, meskipun secara umum diterima bahwa kerangka kerja konseptual yang diuraikan di atas bermanfaat, ia tetap tidak lengkap. Schmitz \& Nadvi (1999) mengidentifikasi dua bidang utama kekurangan dalam teori. Pertama, kerangka kerja efisiensi kolektif gagal untuk secara memadai menangkap pentingnya dan peran hubungan eksternal, yang dapat menjadi penting untuk pengembangan dan keberhasilan cluster. Kedua, jika respons strategis diperlukan untuk tantangan eksternal, tindakan bersama oleh perusahaan lokal mungkin tidak memadai. Ini menyiratkan peran lembaga publik sebagai katalisator atau mediator. Peran lembaga pemerintah dibahas pada bagian 3.4 di bawah ini.

Kerangka Marshallian yang diuraikan di atas menghasilkan wawasan tentang jenis manfaat dalam bentuk spesialisasi tenaga kerja, skala ekonomi dan akses ke pasar yang diperoleh perusahaan dari jaringan kerja sama, dan cenderung berlaku terutama untuk kelompok perusahaan horizontal yang terkonsentrasi secara geografis. Penulis yang lebih baru telah menyelidiki kedua sumber keuntungan jaringan untuk anggota mereka, dan persyaratan struktural yang mendasari manfaat untuk terjadi. Pada yang pertama, Fritsch (2001) membedakan antara manfaat yang diperoleh dari tautan horizontal dan yang diperoleh dari yang vertikal. Selain itu, beberapa manfaat bertambah baik untuk jaringan horisontal maupun vertikal. Fritsch (2001) berpendapat, bahwa, manfaat utama jaringan seperti yang biasanya dijelaskan dalam literatur adalah bahwa mereka memungkinkan perusahaan untuk mewujudkan tingkat pembagian kerja yang relatif tinggi dan, terlebih lagi, dalam hubungan vertikal itulah manfaat ini cenderung untuk terjadi. Dia menyarankan bahwa jaringan tersebut dicirikan oleh hubungan vertikal yang berlebihan, di mana redundansi dalam hubungan bisnis berarti bahwa "terdapat kecenderungan bagi pelanggan untuk memiliki lebih dari satu pemasok barang tertentu dan bahwa pemasok tidak bergantung hanya pada satu pelanggan. Kesimpulan Fritsch (2001) bahwa hubungan vertikal menawarkan keuntungan yang lebih besar kepada perusahaan yang bekerja sama bertentangan dengan banyak literatur di mana fokus tradisional adalah pada hubungan horisontal, dan menunjukkan bahwa aspek hubungan kerjasama ini mungkin memerlukan studi lebih dekat.

Nooteboom (1999), menggunakan apa yang ia sebut pendekatan "konstruktivis", telah mengusulkan dimensi lain ke kerangka kerja konseptual. Dia berpendapat bahwa perusahaan, seperti orang, memiliki pengetahuan berbeda berdasarkan pengalaman mereka. Dia menyarankan bahwa, sebagai akibatnya, fungsi utama perusahaan mungkin bersifat kognitif, dan bahwa perusahaan bertindak sebagai perangkat fokus yang mencapai tujuannya dengan mengarahkan dan menyelaraskan persepsi dan pemahaman orang-orang yang terhubung 
dengannya. Ini menyiratkan bahwa, dengan berfokus pada persepsi tertentu tentang lingkungannya, perusahaan "menanggung risiko kehilangan persepsi peluang dan ancaman dari arah lain ", dan bahwa ada manfaat memiliki akses ke persepsi yang lebih luas atau alternatif selain miliknya sendiri. . Oleh karena itu, jaringan melayani fungsi penting dengan menyediakan sumber kognisi eksternal yang saling melengkapi. Namun, seperti yang dikemukakan Nooteboom (1999: 795): Sumber-sumber luar dari komplementer kognisi membutuhkan 'jarak kognitif' tertentu yang cukup kecil untuk memungkinkan pemahaman tetapi cukup besar untuk menghasilkan pengetahuan baru yang tidak berlebihan. Untuk sumber eksternal untuk mempertahankan kebaruan, sangat penting untuk menjaga jarak. Akuisisi atau merger dapat menghilangkan jarak dan dengan demikian hal baru.

Analisis Nooteboom (1999) dengan demikian setidaknya sebagian membahas kekurangan pertama dari kerangka kerja Marshall yang diidentifikasi oleh Schmitz \& Nadvi (1999), yaitu peran dan pentingnya hubungan eksternal. Memang, implikasi utamanya tampaknya bertentangan dengan kerangka Marshallian. Ketika pendekatan biaya transaksi dari yang terakhir akan menentukan integrasi yang lebih besar dari kegiatan dalam perusahaan yang lebih besar dalam menghadapi ketidakpastian yang lebih besar (misalnya, dari peningkatan kompleksitas dan variabilitas dari kedua teknologi dan pasar), analisis Nooteboom menunjukkan bahwa dalam kondisi ini terdapat kebutuhan yang lebih besar untuk mitra eksternal untuk memberikan kognisi komplementer (Nooteboom, 1999).

\section{Jaringan dan Inovasi}

Jaringan juga memiliki peran untuk dimainkan dalam membantu perusahaan berpartisipasi secara lebih efektif dalam kegiatan terkait inovasi. Seperti DeBresson dan Amesse (1991: 364) berpendapat: Jika inovasi terdiri dari kombinasi teknis baru, jaringan menyediakan fleksibilitas yang dapat digunakan untuk mengeksploitasi peluang untuk rekombinasi berbagai komponen. Jika perusahaan dianggap sebagai kombinasi (sementara) sumber daya, perusahaan inovatif adalah kombinasi baru tetapi bukan satu-satunya bentuk yang mungkin. yang bisa diambil. Jaringan antar perusahaan juga dapat menyediakan sarana rekombinasi, yang memiliki perbedaan keuntungan dibandingkan perusahaan individual. Kombinasi-kombinasi yang mungkin ini dieksplorasi melalui proses "interaksi yang berlebihan" dalam jaringan, sambil menemukan aset pelengkap di luar perusahaan yang diperlukan untuk membuat inovasi itu dapat terus berjalan. 
Dari perspektif yang berbeda, Lundvall (1988) berpendapat bahwa perusahaan kecil yang tidak memiliki kemampuan penelitian dan pengembangan internal dapat mengembangkan jaringan informasi untuk meningkatkan kapasitas penyerapan pengetahuan mereka. Ini terjadi dengan belajar dari pelanggan dan pemasok, berinteraksi dengan perusahaan lain dan mengambil keuntungan dari limpahan pengetahuan dari perusahaan dan industri lain. Koneksi dengan pengguna akhir inovasi juga penting. Sebagai Freeman (1991), mencatat inovasi yang sukses cenderung dicirikan oleh "upaya bertekad untuk mengembangkan pemahaman tentang kebutuhan khusus dan keadaan calon pengguna masa depan dari proses atau produk baru. Kegagalan ditandai dengan pengabaian atau ketidaktahuan akan kebutuhan ini. "Tidak mengherankan, perusahaan dengan personel manajemen yang sangat berkualifikasi lebih mampu menilai kekurangan mereka sendiri dalam hal pengetahuan dan keterampilan teknis, dan untuk terhubung dengan perusahaan atau organisasi lain yang dapat membantu mereka mengatasi kekurangan tersebut.

Sementara perusahaan dari semua ukuran berpartisipasi dalam jaringan, dapat diperdebatkan bahwa manfaat dari partisipasi tersebut berpotensi lebih besar, secara relatif, untuk perusahaan yang lebih kecil, yang cenderung mengalami tingkat yang lebih besar daripada perusahaan besar masalah akses ke informasi dan ke pasar potensial. Vernon (1979) berpendapat bahwa jaringan perusahaan kecil cenderung kurang bersifat global dan lebih berbasis lokal, dengan sumber informasi yang lebih terbatas misalnya, dalam bentuk pertukaran pribadi, pembelajaran kolektif, kerja sama, dan mungkin informasi dari berbasis lokal perusahaan besar atau perusahaan multinasional dalam industri yang sama.

Literatur akan muncul untuk mendukung pandangan bahwa menjadi bagian dari jaringan menurunkan biaya informasi untuk perusahaan dan memungkinkan mereka untuk menghindari masalah pengecualian dan hambatan masuk berikutnya (DeBresson \& Amesse, 1991). Untuk perusahaan dengan departemen penelitian dan pengembangan formal, jaringan dapat mendorong kerjasama dengan perusahaan dan universitas lain dan lembaga penelitian publik lainnya. Bahkan untuk perusahaan yang tidak secara resmi terlibat dalam penelitian dan pengembangan, berpartisipasi dalam jaringan informasi dan pengembangan keterampilan sangat penting dalam membina dan mempertahankan kemampuan untuk terlibat dalam kegiatan inovatif, dan belum tentu bersifat teknologi eksklusif.

Selain itu, hubungan yang terlibat tidak harus langsung berorientasi pada inovasi. Data UK menunjukkan bahwa, secara umum, UKM inovatif memiliki jaringan eksternal padat yang melibatkan perusahaan lain (terutama UKM) dalam berbagai hubungan 
teknis, pemasaran dan manufaktur dan melibatkan lembaga infrastruktur seperti universitas dan lembaga penelitian sektor swasta (Rothwell, 1991). Fleksibilitas hubungan semacam itu menjelaskan mengapa beberapa perusahaan lebih memilih struktur jaringan daripada internalisasi.

\section{Kebijakan dan Peran Lembaga Pemerintah}

Diskusi sebelumnya menunjukkan bahwa masih banyak yang harus dilakukan dalam memajukan pemahaman kita tentang sifat-sifat jaringan, cara-cara di mana mereka menambah nilai bagi anggota mereka, dan bagaimana pembentukan mereka dapat dirangsang dan didorong. Pengalaman Eropa adalah bahwa ketika perusahaan mengelompokkan mereka merasa lebih mudah, karena ekonomi eksternal yang muncul, untuk mengatasi hambatan dalam akses ke input dan ke pasar produk. Namun, seperti yang diperingatkan Schmitz \& Nadvi (1999), "klaster yang sukses tidak dapat dibuat dari awal. Perlu ada sejumlah besar perusahaan dan keterampilan (namun belum sempurna) bahwa bantuan dari luar dapat 'dikaitkan'. "Oleh karena itu, langkah awal untuk merumuskan tindakan kebijakan apa pun dalam hal ini adalah mengidentifikasi apakah ada massa kritis tersebut, atau potensi untuk itu, ada. Schmitz \& Nadvi (1999) menunjukkan, misalnya, pentingnya jaringan perdagangan untuk kelompok yang baru jadi.

Humphrey \& Schmitz (1996) berpendapat bahwa intervensi yang efektif perlu mengikuti apa yang mereka sebut "pendekatan Triple C". Pertama, mereka harus berorientasi customer, untuk memungkinkan perusahaan belajar tentang, dan dari, kebutuhan pelanggan mereka. Ini mendukung penelitian yang menunjukkan bahwa banyak jaringan yang efektif memiliki orientasi pembeli yang kuat. Lebih lanjut, dengan implikasi fokusnya mungkin pada hubungan eksternal juga, karena banyak pembeli tidak akan lokal. Dikemukakan Berry (1997), "bantuan dari kerjasama antar perusahaan cenderung lebih besar dan kerjasama itu lebih mudah dicapai ketika perusahaan yang bekerja sama menjual produk mereka di luar wilayah dan/atau di luar negara".

Kedua, dukungan diarahkan secara lebih efektif secara Colective, yaitu pada kelompok perusahaan daripada pada tingkat perusahaan individu. Ini tidak hanya memiliki biaya transaksi yang lebih rendah tetapi juga mendorong kerja sama dan saling belajar (Schmitz \& Nadvi, 1999). Ketiga, mereka harus Cumulative dalam arti bahwa mereka dapat menghasilkan kapasitas perusahaan dalam jaringan untuk terus meningkatkan dan meningkatkan, sehingga menghindarkan kebutuhan untuk dukungan publik lebih lanjut. Ini 
menyoroti maksud dari banyak kebijakan fungsi katalitik program dukungan pemerintah. Sejumlah penulis (Schmitz \& Nadvi, 1999; Nooteboom, 1999) telah menunjuk kemungkinan peran lembaga pemerintah sebagai katalis atau fasilitator jaringan, atau sebagai mediator dalam jaringan. Menurut Berry (1997), meskipun perantara swasta cenderung lebih efektif dari pada perantara publik, agen pemerintah tetap dapat berkontribusi dengan mengorganisir pameran dagang.

Dalam konteks ini, Berry (1997) menunjuk pada kebijakan Korea untuk mengamanatkan dan memelihara hubungan vertikal yang meningkat, yang memiliki hasil spektakuler dalam memperluas peran UKM dalam perekonomian Korea dalam periode sejak pertengahan 1970-an. Sejauh mana contoh Korea berfungsi sebagai model yang sesuai untuk negara lain adalah pertanyaan yang menarik.

Akhirnya, kepentingan mendasar dari penciptaan lingkungan ekonomi makro yang stabil dan rezim hukum, dan penyediaan tenaga kerja yang terlatih dan berpendidikan melalui fasilitas dan kebijakan pendidikan dan pelatihan yang tepat, harus dipahami sebagai sesuatu yang diberikan (Berry, 1997; Mani, 2002).

\section{KESIMPULAN}

Dari perspektif kebijakan, sejumlah kesimpulan dapat ditarik. Pertama, kebijakan harus berupaya mendorong pembentukan tautan dan jaringan ini. Meskipun tidak jelas peran kebijakan apa yang dimainkan dalam proses mendorong pembentukan jaringan perusahaan, beberapa desentralisasi kebijakan kepada pemerintah daerah dan daerah tampaknya diperlukan dalam kasus cluster geografis dan kawasan industri (Humphrey \& Schmitz, 1995). Levitsky (1996), mengemukakan bahwa bentuk lokasi dan relokasi UKM yang direncanakan mungkin lebih berhasil jika didasarkan pada kelompok atau kawasan industri yang ada. Juga, Humphrey dan Schmitz (1995) melaporkan bahwa intervensi yang berhasil di negara maju dan berkembang cenderung menjadi inisiatif sektor publik / swasta bersama yang sering berfokus pada sektor-sektor tertentu. Kedua, jika bantuan publik untuk UKM dianggap dibenarkan, penyampaian bantuan ini ke jaringan lebih efektif biaya daripada bantuan untuk perusahaan perorangan, karena biaya transaksi lebih rendah. Ketiga, mengingat kelemahan yang cenderung diderita oleh perusahaan kecil dalam hal akses ke personel yang lebih berkualitas, penekanan kebijakan dapat bermanfaat untuk meningkatkan keterampilan perusahaan kecil. Ini memiliki manfaat tambahan bahwa orang-orang yang lebih terlatih dan berkualifikasi lebih mampu menilai kesenjangan teknis dan pengetahuan 
dari perusahaan mereka sendiri dan karenanya lebih mampu menghargai keuntungan membangun hubungan dengan perusahaan dan lembaga lain yang melengkapi dan menambah kemampuan mereka sendiri. perusahaan. Selain itu, pelatihan masyarakat dan program pendidikan harus sesuai dengan kebutuhan UKM, dengan sekolah teknis, lembaga teknis yang sesuai, dan pusat pelatihan lainnya yang terletak, sejauh mungkin, di sekitar cluster dan kawasan industri (Levitsky, 1996).

Seperti yang diamati Berry (1997), pertanyaan kunci bagi pembuat kebijakan adalah: apa peran optimal sektor publik, dan bagaimana perannya bervariasi sesuai dengan situasi? Masih banyak pekerjaan yang harus dilakukan dalam mencapai jawaban, tetapi fakta ini tidak boleh dianggap sebagai resep untuk tidak bertindak mengingat bahwa bobot bukti sangat menunjukkan manfaat yang diperoleh dari jaringan perusahaan koperasi. Dalam artikel ini, kami meninjau argumen kebijakan yang mendukung UKM dalam berbagai bidang operasi mereka. Tinjauan kami menunjukkan bahwa banyak argumen yang diajukan untuk mensubsidi kegiatan UKM (berbeda dari beberapa kegiatan perusahaan terlepas dari ukurannya) tidak dibenarkan secara ekonomi. Meskipun demikian, secara luas diakui bahwa UKM menderita dari kerugian relatif terhadap perusahaan besar, terutama di bidang akses ke informasi dan teknologi.

Penelitian kami terhadap kemungkinan yang ditawarkan oleh jaringan dalam membantu UKM menangani kerugian yang mereka alami menunjukkan bahwa ada manfaat yang dapat diperoleh perusahaan dari berpartisipasi dalam jaringan. Lebih lanjut, karena jaringan dapat membantu perusahaan mengatasi beberapa kerugian bawaan mereka, mereka dapat menjadi kurang bergantung pada bantuan publik dan lebih mampu bersaing dengan pijakan yang sama dengan perusahaan yang lebih besar begitu dorongan awal diberikan untuk pembentukan jaringan kerja sama yang dapat memungkinkan perusahaan untuk bersaing lebih efektif.

\section{DAFTAR PUSTAKA}

American Bar Association (2002), "The Economics of Innovation: A Survey", Section of Antitrust Law, American Bar Association, July.

Andersson, Thomas (2000), "Policy Design, Implementation and Evaluation-Rationale, Efficiency and Systemic Concerns", delivered to the SME Forum on "Public Policies for SMEs in Europe", Lisbon, 13-14 April.

Audretsch, D.B., W.J. Baumol and A.E. Burke (2001), "Competition Policy in Dynamic Markets", International Journal of Industrial Organization, 19, 613-634. 
Basri, E. (2000), "Inter-Firm Technological Collaboration in Australia in an International Context: Implications for Innovation Performance and Public Policy", Working Paper 2000-01, AEGIS, University of Western Sydney.

Belli, Pedro (1997), "The Comparative Advantage of Government: A Review", Working Paper No. 1834, The World Bank.

Berry, Albert (1997), "SME Competitiveness: The Power of Networking and Subcontracting", Inter-American Development Bank, Washington, DC, January.

Bickerdyke, Ian and Ralph Lattimore (1997), "Reducing the Regulatory Burden: Does Firm Size Matter?” Industry Commission Staff Research Paper, Canberra, December.

Clarke, Julian L. and Simon Evenett (2003), "A Multilateral Framework for Competition Policy?" Chapter II in State Secretariat of Economic Affairs Switzerland and Simon J. Evenett (eds.), The Singapore Issues and the World Trading System: The Road to Cancun and Beyond, World Trade Institute.

Cohen, Wesley M. and Daniel A. Levinthal (1989), "Innovation and Learning: The Two Faces of R\&D”, The Economic Journal, Vol. 99, September, 569-596.

DeBresson, C. and F. Amesse (1991), "Networks of Innovators: A Review and Introduction to this Issue", Research Policy, Vol. 20, 363-379.

De Koning, A.C.P., J.A.H. Snijders, and J.G. Vianen (1992), "SME Policy in the European Community", paper presented at Gateways to Growth-Opportunities for Smaller Firms in the EC, cited in Storey (1994).

Freeman, C. (1991), "Networks of Innovators: A Synthesis of Research Issues", Research Policy, Vol. 20, 499-514.

Fritsch, Michael (2001), "Innovation by Networking: An Economic Perspective", in K. Koschatsky, M. Kulicke and A. Zenker (eds.), Innovation Networks: Concepts and Challenges in the European Perspective, Physica-Verlag Heidelberg, 25-33.

Gans, J. S., and John Quiggin (2003), “A Technological and Organisational Explanation for the Size Distribution of Firms", Small Business Economics, 21, 243-256.

Geroski, P. A. (1990), "Innovation, Technological Opportunity and Market Structure", Oxford Economic Papers, Vol. 52, 586-602.

Hall, Chris (2002), Profile of SMEs and SME Issues in APEC 1990-2000, APEC Small and Medium Enterprises Working Group, Singapore: World Scientific Publishing.

Hallberg, Kristin (2000), "A Market-Oriented Strategy for Small and Medium-Scale Enterprises", Discussion Paper No. 40, International Finance Corporation, The World Bank.

Harvie, Charles (2003), "Regional SMEs and Competition in the Wake of the Financial and Economic Crisis", in Tran Van Hoa and Charles Harvie (eds.), New Asian Regionalism: Responses to Globalization and Crises, Palgrave Macmillan, 96-124.

Hawtrey, K.M. (1997), "Finance for Australian SMEs: Policy Issues", Economic Papers, Vol. 16 No. 2, June, 39-50.

Humphrey, John (1995), "Industrial Reorganization in Developing Countries: From Models to Trajectories", World Development, 23(1), 149-162. 
Humphrey, John and Hubert Schmitz (1995), "Principles for Promoting Clusters and Networks of SMEs", paper commissioned by the Small and Medium Industries Branch, United Nations Industrial Development Organization, October.

Humphrey, John and Hubert Schmitz (1996), "The Triple C Approach to Local Industrial Policy", World Development, 24(12), 1859-1877.

Industry Canada (1995), "Competition Policy as a Dimension of Economic Policy: A Comparative Perspective", Occasional Paper No. 7, May.

Lattimore, R., A. Madge, B. Martin and J. Mills (1998), "Design Principles for Small Business Programs and Regulations", Staff Research Paper, Productivity Commission, Australia, August.

Levitsky, J. (1996), "Support Systems for SMEs in Developing Countries: A Review”, Paper commissioned by the Small and Medium Industries Branch, United Nations Industrial Development Organization, March.

Liedholm, Carl and Donald C. Mead (1999), Small Enterprises and Economic Development, London and New York: Routledge.

Lundvall, B. A. (1988), "Innovation as an Interactive Process: From User-Producer Interaction to the National System of Innovation", in G. Dosi, C. Freeman, R. Nelson, G. Silverberg \& L. Soete (eds.), Technical Change and Economic Theory, London: Pinter, 349-369.

Mani, S. (2002), Government, Innovation and Technology Policy: An International Comparative Analysis, Cheltenham: Edward Elgar.

Nooteboom, Bart (1999), "Innovation and Inter-firm Linkages: New Implications for Policy", Research Policy, 28, 793-805.

OECD (2000), "Small and Medium-Sized Enterprises: Local Strength, Global Reach", OECD Observer, June, 1-7.

Parker, Rachel (2000), "Small is Not Necessarily Beautiful: An Evaluation of Policies in Support of SMEs", Australian Journal of Political Science, 35(2), 239-253.

Pacific Economic Cooperation Council (PECC) (2003), "Financing Small and Medium Enterprises: Challenges and Options", Summary Report of the discussion at the Second Annual Conference of the PECC Finance Forum, Hua Tin, Thailand, July.

Rabellotti, Roberta (1995), "Is There an 'Industrial District Model'? Footwear Districts in Italy and Mexico Compared”, World Development, 23(1), 29-41.

Revesz, John and Ralph Lattimore (1997), "Small Business Employment", Industry Commission Staff Research Paper, Industry Commission, Canberra, August.

Rothwell, R. (1991), "External Networking and Innovation in Small and Medium-Sized Manufacturing Firms in Europe", Technovation, 11(2), 93-112.

Scherer, Frederic M. (1970), Industrial Market Structure and Economic Performance, Chicago: Rand McNally.

Schmitz, Hubert and Khalid Nadvi (1999), "Clusteringand Industrialization: Introduction", World Development, 27(9), 1503-1514.

Shrieves, R.E. (1978), "Market Structure and Innovation: A New Perspective", Journal of Industrial Economics, 26, 329-347. 
Storey, D. J. (1982), Entrepreneurship and the New Firm, London and Canberra: Croom Helm.

Storey, D. J. (1994), Understanding the Small Business Sector, London: Routledge.

Symeonidis, George (2000), "Price Competition and Market Structure: The Impact of Cartel Policy on Concentration in the UK", Journal of Industrial Economics, 48(1), 1-26.

Van Cayseele, Patrick and Roger Van den Bergh (2000), "Antitrust Law", in Boudewijn Bouckaert and Gerrit De Geest (eds.), Encyclopedia of Law and Economics, Volume III The Regulation of Contracts, Cheltenham, UK: Edward Elgar, 467-497.

Vernon, R. (1979), "The Product Cycle Hypothesis in a New International Environment", Oxford Bulletin of Economics and Statistics, 41(4), 255-267. 